\title{
The role of miR-29 family members in malignant hematopoiesis
}

\author{
Sona Kollinerova a , Stefano Vassanellib ${ }^{b}$ Martin Modrianskya
}

\begin{abstract}
Aims. MicroRNAs of the miR-29 family members were one of the first microRNAs identified as possible therapeutic agents in malignant hematopoiesis. The aim of our review is to summarize the current state of knowledge on miR-29 family members.

Methods. We performed literature searches involving miR-29 family members and their relationship to individual hematological malignancies, namely acute myeloid leukemia (AML), chronic lymphoblastic leukemia (CLL) and chronic myeloid leukemia (CML). We also searched for subgroups of hematological malignancies, e.g. multiple myeloma, that are regarded as members of the acute or chronic types of leukemias.

Results. A number of genes appear to be regulated by miR-29 family members in various physiological and pathological situations. In our view regulation of TCl-1, Mcl-1 and DNA methyltransferases is relevant in case of hematological malignancies, hence these are the focus of this review. miR-29 family members also function during normal T-cell and B-cell development.
\end{abstract}

Conclusion. MiR-29 family members appear to govern some general features in commonly heterogenous hematological malignancies and therefore form a potential target for treatment.

Key words: microRNA, miR-29, hematopoiesis, leukemia, post-transcriptional regulation

Received: March 3, 2014; Accepted: May 27, 2014; Available online: June 23, 2014

http://dx.doi.org/10.5507/bp.2014.029

${ }^{a}$ Department of Medical Chemistry and Biochemistry, Faculty of Medicine and Dentistry, Palacky University Olomouc, Czech Republic ${ }^{b}$ NeuroChip Laboratory, Department of Biomedical Sciences, University of Padova, Italy Corresponding author: Martin Modriansky, e-mail: martin.modriansky@upol.cz

\section{INTRODUCTION}

MicroRNAs (miRNAs) were identified as short, noncoding RNAs, that are 19-25 nucleotides long ${ }^{1}$. Large body of evidence shows that miRNAs are important regulators of protein expression and participate in a number of fundamental biological processes, e.g. in the development of the embryo, cell proliferation, cell growth, tissue differentiation, and apoptosis. Mutations in miRNA sequences, dysfunction of miRNA biogenesis and dysregulation of miRNA expression can contribute to a wide spectrum of diseases. The most common change in expression of miRNAs was found in neoplasms, where miRNAs were reported involved in tumorigenesis by targeting tumor suppressor genes or oncogenes, both directly or indirectly ${ }^{2}$.

MiRNA expression is a dynamic process that reflects changes in the physiological situation on the cellular level. The increased or decreased expression of different miRNAs was found to correspond with different settings, including diagnosis of the disease, evaluation of prognosis and prediction of response to treatment. It is thus possible to use miRNA expression profiles derived from tumor specimens as diagnostic or prognostic biomarkers ${ }^{3}$.

While hematological disorders are not the most common malignancies within human population, they earned special attention because of successful treatments based on genetical information. A hallmark case is chronic myeloid leukemia (CML) with Philadelphia chromosome and the development of imatinib. Therefore we focused our attention to hematological disorders in relation to a gene family of miR-29 family members which appear to play a role in hematological malignancies.

\section{MiR-29 family members}

MiR-29 is present in three family members: miR-29a, miR-29b and miR-29c. There are two bi-cistronic clusters of miR-29: the miR-29a/b-1 cluster and the miR-29b-2/c cluster. Mir-29b-1 is located along with miR-29a on chromosome 7 and miR-29b-2 lies in the same area as the miR-29c on chromosome 1 . The mature sequences of miR-29b-1 and miR-29b-2 are identical, while miR-29a and miR-29c differ from miR-29b and are distinguished from each other by a difference in only a single nucleotide outside the seed sequence. Each member of microRNA family is characterized by the same "seed region" and therefore microRNA family members overlap in their predicted mRNA targeting ${ }^{4}$. Despite similar sequences, the miR-29 family members have different subcellular occurrence: as miR-29a is mainly cytoplasmic, miR-29b is more abundant in the nucleus ${ }^{5}$. While polycistronic primary transcript contains both miR-29a/miR-29b-1, subcellular localization of both mature miR-29a and miR-29b is dif-

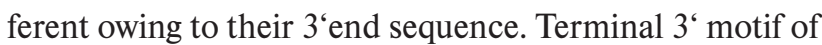
AGUGUU in mature miR-29b is responsible for its import into the nucleus where it may act as a transcription or splicing regulator, a role distinct from the one commonly ascribed to miRNAs 5 .

Currently several target genes regulated by miR-29 are known. Prominent among them are T-cell leukemia oncogene (Tcl-1), myeloid cell leukemia sequence 1 
(Mcl-1) and DNA methyltransferases (DNMT) 3A and 3B. However, we believe that many target genes are still unknown ${ }^{6-8}$.

\section{Regulation of miR-29 expression}

Although studies involving microRNA evolved immensely during the last couple of years, most of the scientific effort focused on identification of microRNA target genes rather than understanding the regulation of microRNA genes. Promoters and regulation elements remain one of the interesting areas of investigations into microRNA regulation. On the other hand, the posttranscriptional regulation at the level of primary miRNA, extranuclear transport and further processing leading to miRNA maturation, may display individual differences among miRNAs. While a number of regulation mechanisms governing miR-29 expression were observed in various cell types, the basics of miR-29 regulation is still a matter of debate.

There are two means of miR-29 family regulation. One is by incidence of transcription factors in the promoter region and the second is by post-transcriptional regulation. Differences between the promoter regulation of the miR-29a/b-1 and miR-29b-2/c clusters may be responsible for the inconsistent ratio of miR-29a, miR-29b and miR29 c expression across tissues ${ }^{9}$. Summary of regulation of miR-29 clusters by transcription factors is shown in Fig. 1.

Binding sites for the transcription factor Myc were identified in the promoter region of both miR-29 clusters. Myc is an oncogenic transcription factor, which is pathologically activated in many human malignancies. It was shown that Myc negatively regulates expression of all miR-29 family members ${ }^{10}$. Investigation of transcrip- tional suppression of miR-29b-1/a promoter by c-Myc, Hedgehog and NF-kB was conducted in cholangiocytes. The miR-29b-1/a promoter region contains a canonical E-box Myc binding site and enforced expression of c-Myc decreased promoter activity by $50 \%$. The data confirm suppression of miR-29 expression by c-Myc. Moreover, it was demonstrated that miR-29b-1/a promoter contains Gli binding site which can be regulated by hedgehog pathway. Increased miR-29b expression suggested constitutive hedgehog signaling in cholangiocarcinoma cells and demonstrated that this pathway repressed miR-29b expression. The data also supported the role of NF- $\kappa \mathrm{B}$ activation through TLR signaling as a suppressor of miR$29 \mathrm{~b}-1 /$ a promoter function and expression of mature miR$29 \mathrm{~b}$ through recognition of NF-kB binding sites located in the miR29b-1/a promoter region ${ }^{11}$.

CCAAT/enhancer binding protein $\alpha$ (CEBPA) binding site was identified in miR-29b-1/a promoter ${ }^{12}$. Because CEBPA activated promoter and thereby positively regulated expression of miR-29b in acute myeloid leukemia (AML) more detailed overview is given in the AML section.

The miR-29b-1/a promoter region also includes two binding sites for T-cell factor/lymphoid enhancer factor (TCF/LEF) which is necessary for osteoblast differentiation. MiR-29a expression is induced by canonical Wnt signaling. This effect is mediated by two TCF/LEF binding sites within the proximal promoter and is necessary for osteoblast differentiation ${ }^{13}$.

Recent study unveiled the ability of interferon $\gamma$ to regulate the pri-miR-29a/b-1 cluster expression in melanoma ${ }^{14}$. Interferons are cytokines that modulate the natural immune response, however, they also have strong

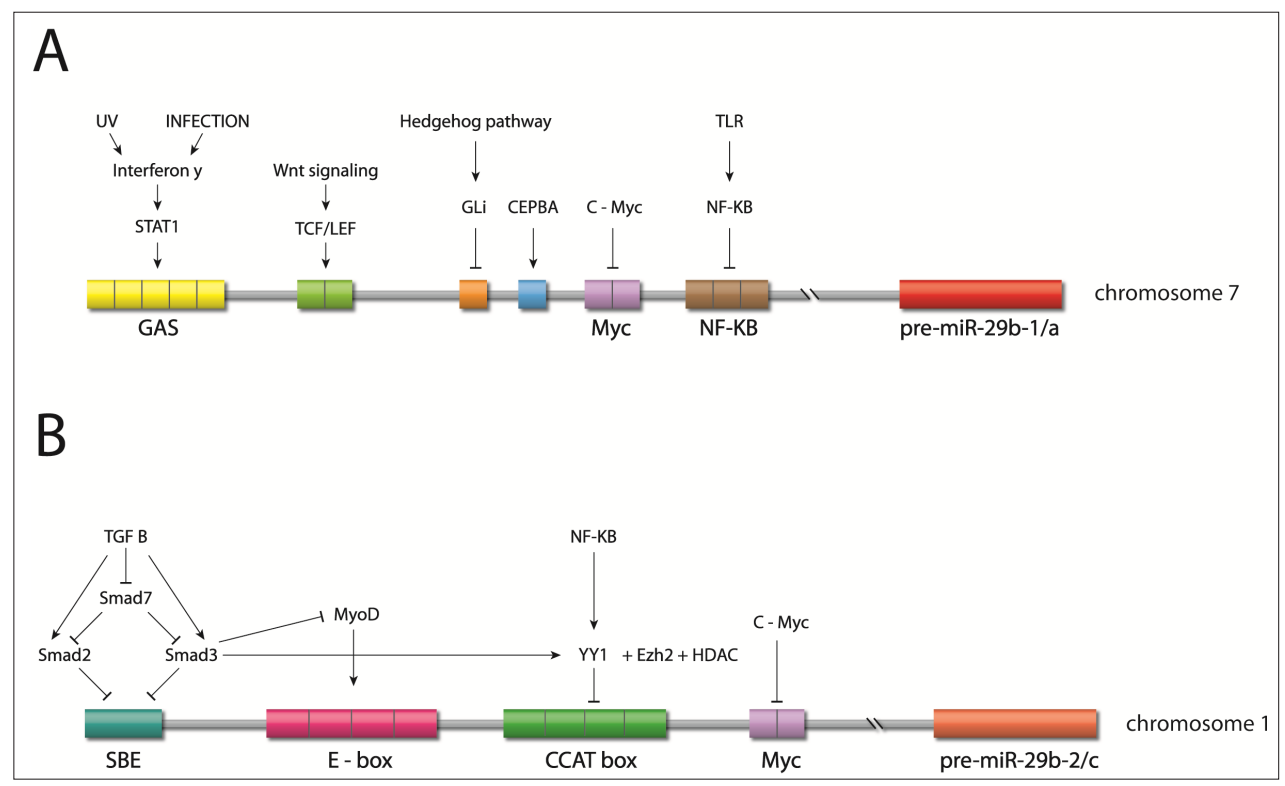

Fig. 1. Regulation of miR-29 clusters by transcription factors on chromosome 1 and 7 .

Panel A - Regulation of pre-miR-29b-1/a cluster on chromosome 7. Negative regulation was shown for transcription factors Gli, C-Myc and NF-kB. Positive regulation (arrows) was shown for STAT1, TCL/LEF and CEBPA. Panel $B$ - Regulation of pre-miR-29b-2/c cluster on chromosome 1. Negative regulation was shown for TGF $\beta$ through Smad2/3, YY1 and C-Myc. Positive regulation was mediated by MyoD. 
anti-proliferative activity. Interferon $\gamma$ inhibits malignant cell growth by activating transcriptional factor STAT1. Following interferon $\gamma$ stimulation by infection or UV light STAT1 induction ensues ${ }^{15}$ causing formation of homodimers of the factor and their binding to GAS (IFN $\gamma$ - activated sequences) element in the promoter region of target genes ${ }^{16}$. Predicted promoter region of pri-miR-29a/b-1 contains five GAS elements. It was shown that interferon $\gamma$ induces STAT1 dependent increase of the primary cluster pri-miR-29a/b-1, and hence the expression of miR-29a and miR-29b, while the level of pri-miR$29 \mathrm{~b}-2 / \mathrm{c}$ remains undetectable. In this case the increased miR-29a and miR-29b expression results in diminished expression of CDK6, ultimately leading to the cell cycle arrest in the G1 phase of melanoma cells ${ }^{14}$.

It was found that during myogenesis is miR-29 the target gene of the NF-kB-YY1 signaling pathway. The study identified a regulation element localized approximately $20 \mathrm{~kb}$ upstream of miR-29b-2/c cluster on chromosome 1 . The element consists of four YY1 binding sites that are associated with transcriptional repressor factors Polycomb group (PcG) Ezh2 and HDAC1. Interestingly, there were no YY1 binding sites identified on chromosome 7 on which the miR-29a/b-1 cluster is localized. The result suggests that YY1 and PcG complex bind the regulation element hence causing epigenetic repression of miR-29b-2/c transcription in progenitor muscle cells ${ }^{17}$. It was found previously that YY1 in myoblasts is under positive regulation by the transcriptional factor NF- $\mathrm{BB}$ $\left(\right.$ ref. $\left.^{18}\right)$. Therefore it was confirmed that NF- $\kappa \mathrm{B}$ negatively regulates miR-29 expression. Lower activity of NF- $\mathrm{kB}$ and YY1 in conjunction with higher miR-29 expression during differentiation of skeletal muscle cells demonstrates the role of miR-29 in normal myogenesis ${ }^{17}$.

Recently a new regulator of miR-29 expression was identified as tumor growth factor $\beta$ (TGF- $\beta$ ) (ref. ${ }^{19}$ ). TGF- $\beta$ is one of the strongest fibrogenic cytokines that causes induction of trans-differentiation of myogenic cells to myofibroblasts and muscle myogenesis ${ }^{20}$. Following TGF- $\beta$ binding to its receptor the signal is relayed by phosphorylation of Smad 2 and Smad3, which are both translocated into the nucleus where they regulate expression of a number of target genes. In case of fibrotic genes it binds to the promoter region of Smad Binding Element (SBE). TGF- $\beta$ may also inhibit Smad7, an inhibitor of Smad2/3, hence providing the negative feedback ${ }^{21}$. Promoter region of mouse miR-29b-2/c contains four E-box binding sites for MyoD with close proximity to SBE. Independently of these sites the CCAT box binding YY1 is located ${ }^{22}$. MyoD is a transcriptional factor influencing differentiation of skeletal muscle cells ${ }^{23}$. A new mechanism by which $\mathrm{Smad} 3$ influences MyoD binding to the E-box and concurrently binding of YY1 to the CCAT box was uncovered. TGF- $\beta$ activates Smad3 which then binds to the SBE therefore preventing the binding of MyoD to the E-box that lies in close proximity and allows YY1 binding to the Ezh2 And HDAC1 complex at the same time resulting in inhibition of miR-29 transcription. If Smad3 is not activated by TGF- $\beta$, MyoD would bind to the promoter E-box and transcription of miR-29 follows. Therefore TGF- $\beta$-Smad 3 signaling pathway modulates the miR-29 expression by two mechanisms ${ }^{22}$.

Post-transcriptional manner of miR-29 regulation was observed in HeLa cells. Although the clusters of miR29a/b-1 and miR-29b-2/c were co-transcribed, the mature miR-29 family members show differential expression. MiR-29a was detected in all stages of cell cycle, miR-29b was found only during mitosis and miR-29c was not detected $^{5}$. Others demonstrated that the differences between miR-29a and miR-29c result in the relatively quicker decay of miR-29c (ref. $\left.{ }^{24}\right)$.

\section{Mir-29 family members in normal and malignant haematopoiesis}

miR-29 family members play an important role in life of $\mathrm{T}$ and $\mathrm{B}$ cells. Thymus is essential for T cell differentiation and atrophy of the thymus, termed thymic involution, results in a $>90 \%$ reduction in thymus size and a reduction in $\mathrm{T}$ cell generation. One of the key mechanisms by which thymic involution is driven during infection is through type I interferons (IFN $\alpha, \beta)$ produced by the pathogen sensing pathway ${ }^{25}$. Production of type I IFN signaling occurs through a common receptor IFN $\alpha / \beta$ receptor (IFNAR), which is expressed by nearly all cell types. Binding to IFNAR activates the Jak/Stat pathway, which protect the cell against infection ${ }^{26}$. The mechanism for tuning type I IFN signaling in thymic epithelial cells is set by miR-29a/b-1 expression, which inhibits the production of IFNAR1 ( ref. $^{27}$ ). MiR-29a/b-1 does have a critical function in supporting $\mathrm{T}$ cell production in a $\mathrm{T}$ cell extrinsic manner, namely a function in preventing inappropriate thymic atrophy ${ }^{28}$.

$\mathrm{T}$ cell maturation is based on one of the most fundamental decision between the fates of Th1 cellular immunity, with strong IFN $\gamma$ production, or Th2 humoral immunity, with strong IL-4 production. It is likely that miR-29 suppresses the Th1 fate by targeting three genes IFN $\gamma$, T-bet and Eomes and that enhanced expression of T-bet and Eomes largely functions to reduce the threshold of Th1 induction, with expression levels normalized following polarization by feedback mechanisms ${ }^{29,30}$. These two studies suggest three functions of miR-29a/b in mature T cells. Firstly, the expression of miR-29a/b is critical for setting the threshold for the Th1/Th2 cell fate decision. Secondly, down-regulation of miR-29a/b following exposure to intracellular bacteria initiates a positive feedback loop of enhanced IFN $\gamma$ production and increased resistance to infection. Thirdly, miR-29a/b likely plays a similar role in the CD8 T cell and NK cell lineages, miR$29 \mathrm{a} / \mathrm{b}$ reduce exposure to intracellular bacteria and have enhanced IFN $\gamma$ production in miR-29 transgenic mice ${ }^{28}$.

The miR-29 family has important functions in B cells, as suggested by significant enrichment of B cell signaling pathways among miR-29 targets. As we described previously, several associations exist between miR-29 family members and variety of malignant hematopoieses. Summary of these associations is shown in Fig. 2. We can hypothesize that the various factors influencing expression of miR-29 family members and their target could be linked across diseases. Therefore, monitoring of other 




Fig. 2. Summary diagram of miR-29 family members regulation and their target genes within various hematopoietic malignancies. The first box shows the factors affecting the expression of miR-29. The third box contains the known target genes of miR-29 whose changes affect the process of hematopoietic malignancies listed in the fourth box. Individual superscripts indicate which factors are affected in which disease.

factors or biomarkers than those already in force for a hematological malignancy may unveil previously unknown associations and cross-talks.

\section{Target genes of miR-29}

According to computational analyses miR-29 may have as many as 6000 predicted target genes ${ }^{31}$. However, only 24 of the predicted targets were experimentally validated using multiple methods (Table 1). Therefore it appears that miR-29 family could play important roles across many cellular processes ranging from differentiation, affecting immune response, extracellular matrix structure, cell proliferation to apoptosis ${ }^{31}$.

Relationship between miR-29 expression and extracellular matrix proteins was investigated for example for Collagens and Matrix metalloproteinase 2 (MMP2) (ref. ${ }^{22,32-36}$ ). In myogenic differentiation and skeletal myogenesis target genes influenced by miR-29 family members expression were also found, for example TGF- $\beta$, HDAC4 or YY1 (ref. ${ }^{17,19}$ ). Role of miR-29 family members expression in immune response was observed on B7-H3 and interferon $\gamma$ (ref. ${ }^{29,37}$ ). Currently a number of target genes affected by miR-29 family members in variety of cancers were identified. Some of them, which we consider relevant for this review, are discussed in greater detail in the following text.

\section{MiR-29 as a regulator of Tcl-1}

The Tcl-1 oncogene was discovered as a target of frequent chromosomal rearrangements at $14 \mathrm{q} 31.2$ in mature T-cell leukemias ${ }^{59}$. Tcl-1 is a coactivator of the Akt oncoprotein, a critical molecule in the transduction of antiapoptotic signals in $\mathrm{B}$ and $\mathrm{T}$ cells ${ }^{60}$. It was confirmed that high levels of Tcl-1 correlates with unmutated $\mathrm{VH}$ status and Zap70 positive patients with aggressive form of B-cell chronic lymphocytic leukemia (B-CLL). High level of Tcl-1 also indicates the aggressive form of B-CLL (ref. ${ }^{61}$ ). In 2006 it was reported for the first time that Tcl-1 mRNA expression is inhibited by miR-29 and miR-181 and that their levels correlate with the form of B-CLL. MiRNA expression profiling and Tcl-1 western blot detection was carried out for three types of CLL: indolent CLL, aggressive CLL, and aggressive CLL showing 11q deletion. Results of these experiments demonstrated that Tcl-1 over-expression correlates with aggressive B-CLL phenotype and aggressive B-CLL with 11q deletions. Using transfection experiments it was revealed that coexpression of Tcl-1 with miR-29 significantly decreased Tcl-1 expression. The conclusion was that Tcl-1 expression is regulated by miR-29 and miR-181 and this regulation is relevant to the three groups of B-CLL studied. The fact that neither miR-29 nor miR-181 is located at $11 \mathrm{q}$ chromosomal region suggests that deletions in this region may affect an unknown regulator of the expression of these two microRNAs ${ }^{6}$. These results were confirmed by Stamatopoulos et al. who showed that miR-29c negative patients expressed significantly higher levels of Tcl-1 compared with miR-29c positive patients ${ }^{62}$.

To study the role of miR-29 in B-CLL, E $4-m i R-29$ transgenic mice overexpressing miR-29 in B cells were generated. At 2 month of age $85 \%$ of the transgenic mice exhibited expanded CD5+ B-cell populations, a characteristic of B-CLL. At 2 years of age the mice showed significantly enlarged spleens. Of these mice $20 \%$ developed leukemia and subsequently died of the disease. These results suggest that dysregulation of miR-29 may contribute to the pathogenesis of indolent B-CLL $\left(\right.$ ref. $^{32}$ ).

\section{MiR-29 as a regulator of Mcl-1}

Myeloid cell leukemia sequence 1 (Mcl-1) is an antiapoptotic protein of the Bcl-2 family containing Bcl-2homology domains $\mathrm{BH} 1-3$ that heterodimerizes with 
Table 1. Validated miR-29 target genes. Data were adopted from miRTarBase ${ }^{38}$.

\begin{tabular}{|c|c|c|c|}
\hline Target gene & Ref. & Regulated by miR-29 family member & Validation method \\
\hline COL1A1 & $35,39,40$ & $\operatorname{miR}-29 b$ & RA, WB, qPCR, microarray \\
\hline SP1 & 39,41 & $\operatorname{miR}-29 b$ & RA, WB, qPCR, microarray \\
\hline CDK6 & 8,42 & miR-29a, miR-29b, miR-29c & RA, WB, qPCR \\
\hline DNMT3A & 43,44 & miR-29a, miR-29b, miR-29c & RA, WB, qPCR, microarray \\
\hline DNMT3B & 41,43 & miR-29a, miR-29b, miR-29c & RA, WB, qPCR \\
\hline COL4A1 & 40,45 & miR-29a, miR-29b & RA, WB, qPCR \\
\hline COL4A2 & 45,46 & $\operatorname{miR}-29 \mathrm{a}$ & RA, WB, qPCR \\
\hline Mcl-1 & $7,40,42,44,47,48$ & miR-29a, miR-29b, miR-29c & RA, WB, qPCR, microarray \\
\hline Bcl-2 & 48 & miR-29a, miR-29b, miR-29c & RA, WB, qPCR \\
\hline SFRP2 & 13 & $\operatorname{miR}-29 a$ & RA, WB, qPCR \\
\hline DKK1 & 13 & $\operatorname{miR}-29 a$ & RA, WB, qPCR \\
\hline PPM1D & 49 & $\operatorname{miR}-29 \mathrm{a}$ & RA, WB, qPCR, microarray \\
\hline PIK3R1 & 50 & $\operatorname{miR}-29 a$ & RA, WB, qPCR \\
\hline Tcl-1A & 6,51 & $\operatorname{miR}-29 b$ & RA, WB, qPCR, microarray \\
\hline KREMEN2 & 13 & $\operatorname{miR}-29 a$ & RA, WB, qPCR \\
\hline GRN & 52 & $\operatorname{miR}-29 b$ & RA, WB, qPCR \\
\hline COL3A1 & 40,53 & $\operatorname{miR}-29 b$ & RA, WB, qPCR \\
\hline MMP2 & 40 & $\operatorname{miR}-29 b$ & RA, WB, qPCR \\
\hline LPL & 54 & $\operatorname{miR}-29 a$ & RA, WB, qPCR \\
\hline HMGA2 & 55 & $\operatorname{miR}-29 b$ & RA, WB, qPCR \\
\hline SAPCD2 & 56 & $\operatorname{miR}-29 a$ & RA, WB, qPCR \\
\hline SPARC & 33,57 & $\operatorname{miR}-29 a$ & RA, WB, qPCR, microarray \\
\hline SERPINB9 & 59 & $\operatorname{miR}-29 a$ & RA, WB, qPCR, microarray \\
\hline BACE1 & 58 & $\operatorname{miR}-29 c$ & RA, WB, qPCR \\
\hline
\end{tabular}

Listed are those target genes that were validated by all three methods of reporter assay (RA), western blotting (WB) and/or quantitative PCR (qPCR). Several genes were also evaluated using microarray technology in addition to the three other methods. Relevant references for each target gene are given in second column.

Bcl-2 family members. Mcl-1 is able to inhibit pro-apoptotic BH3-only proteins Bim, Bid, Bik, Noxa, Puma and Bak. Binding of Mcl-1 to Bid and Bim protects against tumor necrosis factor-related apoptosis-inducing ligand (TRAIL) induced cell death ${ }^{63}$. Its regulation is necessary because the lack of Mcl-1 causes death and conversely its over-expression can lead to tumor transformation ${ }^{64}$.

Computer-based programs such as TargetScan, miRANDA, PicTar and miRBase Targets were used to predict microRNAs that potentially bind Mcl-1 (ref. ${ }^{7,65}$ ). The three family members of miR-29 (a, b, c) share the first 9 nucleotides with minor divergence thereafter, suggesting all miR-29 family members potentially target Mcl-1. Moreover, there is perfect complementarity between miR$29 \mathrm{~b}$ and the 3'UTR of Mcl-1 and this binding site is conserved across various species ${ }^{7}$.

In 2007 scientists investigated the expression of miR29 in human immortalized, but non malignant H69 cholangiocyte and malignant $\mathrm{KMCH}$ cholangiocarcinoma cell lines because Mcl-1 is dysregulated in cells with the malignant phenotype. They found, that miR-29b was highly expressed in cholangiocytes and down-regulated in malignant cells, what is consistent with Mcl-1 protein up-regulation. Enforced miR-29b expression reduced $\mathrm{Mcl}-1$ protein expression in the malignant $\mathrm{KMCH}$ cells and over-expression of miR-29b sensitized the cancer cells to TRAIL cytotoxicity. H69 which expressed high levels of miR-29 was transfected with a locked-nucleic acid antagonist of miR-29b. Mcl-1 levels was increased and TRAILmediated apoptosis was reduced ${ }^{7}$.

Monitoring of miR-29 family members expression in three human myeloma cell lines (HMCLs) SKO-007, U266 and XG7 revealed that miR-29b was significantly down-regulated in all three cell lines, compared with miR29a and miR-29c. Transfection of two HMCLs (SKO-007, XG7) with adenoviral vector Ad5f11p-CMV-miR-29b caused a significant increase of miR-29b and western blot analysis demonstrated that the over-expression of miR-29b dramatically down-regulated Mcl-1 protein levels in a timedependent manner. The inhibition of target gene expression by miR-29b is not mediated by mRNA degradation because Mcl-1 mRNA expression was not altered by the 
over-expression of miR-29b. Over-expression of miR-29b in HMCLs also led to growth inhibition and apoptosis induction through caspase- 3 activation. Further, the relationship between miR-29b expression and IL-6 activity during Mcl-1 expression in MM was analyzed. Results demonstrated that miR-29b at least partially interrupts the process of IL-6-induced up-regulation of Mcl-1 and suppresses the protective effect of IL- 6 in myeloma cells. These observations indicate that miR-29b could be an important regulator of myeloma cells and may be involved in the progress of multiple myeloma pathology ${ }^{65}$.

\section{MiR-29 as a regulator of DNA methyltransferases}

Methylation changes to the epigenome are controlled by DNA methyltransferases (DNMTs), which catalyze the transfer of a methyl group from S-adenosyl methionine to the carbon 5 position of cytosine in the context of the sequence $5^{6}$-cytosine-guanosine $(\mathrm{CpG})$ (ref. $\left.{ }^{66}\right)$. The promoter regions of approximately $50 \%$ of human genes contain regions of DNA with $\mathrm{CpG}$ islands greater than expected and their hypermethylations mediate transcriptional gene silencing ${ }^{67}$. Three catalytically active DNMTs have been identified in mammals: DNMT1, DNMT3A and DNMT3B. Whereas DNMT1 preferentially replicates already existing methylation patterns, DNMT3A and 3B are responsible for establishing de novo methylation and can introduce methyl groups on the parental template strands of DNA (ref. ${ }^{68}$ ). The levels of DNMTs mRNA are reportedly elevated in various malignancies.

Hypermethylation is responsible for the silencing of tumor suppressor genes involved in lung carcinogenesis such as CDKN2A, CDH13 (ref. ${ }^{69}$ ), FHIT, WWOX (ref. ${ }^{70,71}$ ), CDH1 and RASSF1A (ref. ${ }^{72}$ ). It was demonstrated that expression of miR-29 is down-regulated in non-small-cell lung cancer (NSCLC) ( ref. $^{73}$ ). Computer-based programs PicTar, TargetScan, miRANDA and miRGen predicted an intriguing complementarity of miR-29 family members to sites in the 3'UTR of DNMT3A and 3B. Over-expression of individual miR-29 family members induced marked reduction of DNMT3A and 3B levels. On the other hand, silencing of miR-29 with antisense molecules induced upregulation of DNMT3A and 3B mRNA levels. In addition, DNMT3B mRNA was more significantly reduced by expression of miR-29 than the 3A. It was probably caused by the more predicted match "seeds" between miR-29 and the 3'UTR of DNMT3B than the 3'UTR of DNMT3A. A statistically significant inverse correlation was observed between DNMT3A and 3B mRNA and miR-29a and miR29c in NSCLC. Enforced expression of miR-29 leads to reduced DNA methylation and restores expression of tumor suppressor genes such as FHIT and WWOX mRNA levels and inhibits tumorigenicity ${ }^{43}$.

Regulation of DNMTs by miR-29 was also found in acute myeloid leukemia. In this study it was demonstrated that expression of miR-29b promotes DNA hypomethylation not only through direct targeting of DNMT3A and $3 \mathrm{~B}$ but also by decreasing the DNMT1 expression indirectly via down-regulation of $\mathrm{Sp} 1$, a known transactivating factor of the DNMT1 gene. Transfection and following over-expression of miR-29b resulted in global
DNA hypomethylation and gene re-expression of the hypermethylated and silenced $\mathrm{p} 15^{\mathrm{INK} 4 \mathrm{~b}}$ and ESR1 in AML cell lines ${ }^{41}$. Re-expression of these genes correlates with clinical response in patients treated with the hypomethylating agent decitabine ${ }^{74}$. Therefore, combining DNMT1 inhibitors (decitabine or azacitidine) with synthetic miR$29 \mathrm{~b}$ may result in a synergistic hypomethylating effect ${ }^{41}$.

The same result of miR-29 regulating DNMT3A and 3B was found in primordial germ cells of mouse embryos. Moreover, the most abundant miRNA on both sexes, miR-29b, is preferentially expressed in the female gonad. MiR-29b may play an important role in female gonadal development by targeting DNMT3A and 3B and thereby modulating methylation of genomic DNA in primordial germ cells ${ }^{75}$.

Down-regulation of miR-29c and hypermethylation of tumor-related genes is also associated with disease outcome in cutaneous melanoma. All three miR-29 family members were found to have lower expression in stage III and IV metastases compared to stage I/II primary tumors. Expression of miR-29c significantly decreased in metastatic tumors. Expression of both DNMT3A and 3B was found significantly higher in stages III and IV metastatic melanomas compared to stage I/II primary melanomas. MiR-29c expression was inversely correlated to DNMT3A and $3 \mathrm{~B}$ expression. These studies demonstrated that the miR-29c is a potential clinicopathological biomarker for differentiating between individual melanoma stages and its down-regulation may be indicative of aggressive disease $^{76}$.

\section{Role of miR-29 in individual hematopoietic malignancies}

Mir-29 and its role in chronic lymphocytic leukemia (CLL)

CLL is the most common leukemia in the Western world and occurs in two forms, aggressive and indolent. Clinical features and genomic abnormalities in CLL were studied but molecular mechanisms underlying disease development are still emerging ${ }^{77}$. Many studies have confirmed that miR-15a and miR-16-1 play an important role in the pathogenesis of CLL. They act as tumor suppressors because they target multiple oncogenes, including Bc12, Mc11, CCND1 and WNT3A which lead to inhibition of cell proliferation, promote apoptosis of cancer cells and suppress tumorigenicity ${ }^{78}$. MiR-15a and miR16-1 are located on chromosome 13 in the 13 q 14.3 region, which is deleted in more than $55 \%$ of CLL patients. Allelic loss in this region correlates with down-regulation of both miRNAs expression ${ }^{79}$. It was demonstrated that restoration of miR-15a and miR-16-1 triggers apoptosis and suppresses tumorigenicity. It could be concluded that these miRNA genes play an important role in regulating apoptosis in CLL (ref. ${ }^{80}$ ).

Current knowledge suggests the dysregulation of Tcl-1 oncogene to be involved in the pathogenesis of the aggressive form of this disease ${ }^{6}$. Tcl- 1 was first identified as a target of translocations and inversions at $14 \mathrm{q} 32.1$, common chromosomal aberrations in T-cell prolymphocytic 
leukemia $^{59}$. Tcl1 is co-activator of the Akt oncoprotein, which is a critical molecule in the transduction of antiapoptotic signals in $\mathrm{B}$ and $\mathrm{T}$ cells ${ }^{81}$. It was found that $\mathrm{Tcl} 1$ activation caused CLL by activation of NF-kB pathway and inhibition of AP-1 (ref. ${ }^{82}$ ). It was shown that expression of miR-29 could discriminate between CLL samples with good and bad prognosis. It was found that miR-29 is up-regulated in indolent B-CLL compared to aggressive B-CLL where miR-29 expression is down-regulated ${ }^{83}$. Experiments helped to identify the target gene of miR-29 in CLL as Tcl-1 and expression levels of miR-29 inversely correlated with Tcl-1 expression in the CLL samples.

Aggressive CLL with poor prognosis were associated with chromosomal aberrations in tumor-suppressor gene TP53 that codes for p53 protein involved in cellular response to DNA damage. It was found that patients with deletions and/or mutations in the TP53 gene had several microRNAs down-regulated, among them miR-29c $\left(\right.$ ref. $\left.{ }^{47}\right)$. The data fit with an in vitro study performed in HeLa cells, which is not a leukemia cell line, however, the data support indirect activation of $\mathrm{p} 53$ by miR-29 family members ${ }^{50}$. Taken together, it offers an intriguing hypothesis of a feedback loop between p53 and miR-29c in CLL.

Study by Sampath et al. considered the epigenetic effect on regulation of miRNA expression in CLL (ref. ${ }^{84}$ ). They showed that the histone deacetylases (HDACs) are overexpressed in CLL and mediate the epigenetic silencing of miR-15a, miR-16 and miR-29b. In approximately $35 \%$ of samples HDAC inhibition triggered the accumulation of the transcriptionally activating chromatin modification and restored the expression of miR-15a, miR-16 and miR-29b. Induction of miR-15a, miR-16 and miR-29b in response to HDAC inhibition is associated with decreases in the levels of the survival protein Mcl-1, loss of mitochondrial function and activation of cell death ${ }^{84}$. One hypothesis states that STAT3, which is the signal transducer and activator of transcription 3, mediates epigenetic silencing of a variety of genes, in particular genes that affect HDACs. Therefore STAT3 may induce epigenetic silencing of various miRNAs in CLL cells ${ }^{85}$. Moreover, unphosphorylated STAT3 detected at high levels in CLL cells constitutively activates the transcription factor nuclear factor $\kappa \mathrm{B}$, which is known to induce the production of several pro-inflammatory cytokines and activate survival pathways $^{86}$.

Another study inferred that some miRNAs can regulate surface-immunoglobulin B cell receptor (BCR) complex expressed by CLL cells ${ }^{87}$. BCR-regulated miRNA could contribute to the orchestration of $\mathrm{B}$ cell proliferation, apoptosis or sensitivity to BCR signaling. In turn, BCR stimulation can alter the expression of microR$\mathrm{NAs}^{87}$. Many of the miRNAs that are affected by BCRstimulation in CLL and normal $B$ cells are also those that are differentially expressed between cases of CLL with favorable versus unfavorable prognosis. For example, activation via BCR ligation can reduce the levels of miR-29c, miR-150, miR-181b or miR-223 and relatively low-levels expression of these miRNAs was found in CLL cells of patients with shorter overall survival ${ }^{88}$.
It is known that miRNA expression in CLL is influenced by aberrant methylation and acetylation of their promoter regions, which could be due to the response to BCR stimulation. In these situations, the use of histone deacetylases can restore miRNA expression and sensitize CLL cells to apoptotic stimuli ${ }^{84}$.

Mantle Cell Lymphoma (MCL) is one of the most aggressive B-cell lymphomas, a disease biologically similar to CLL. Hybridizing miRNA array with RNAs from 39 patients with MCL revealed that 21 miRNAs were upregulated and 18 miRNAs, including miR-29 family members, were down-regulated. Diminished expression levels of the miR-29 family members are associated with short overall survival of patients with MCL. It was found that miR-29 directly regulates CDK6 and inverse correlation between miR-29 and CDK6 was observed in MCL cell lines and primary tumor specimens. The elevated CDK6 cooperates with cyclin D1 to further promote cell-cycle progression. These findings indicate that deregulation of miRNA is a common event in MCL and that miR-29 could be a valuable prognostic marker and pathogenetic factor in MCL $\left(\right.$ ref. $\left.^{8}\right)$.

Mir-29 and its role in acute myeloid leukemia (AML)

AML is a heterogeneous disorder characterized by uncontrolled proliferation of hematopoietic progenitors and a blockage in myeloid differentiation is major characteristic of AML ( ref. $^{89}$ ). Many different cytogenetic and molecular abnormalities were demonstrated in tumorigenesis of AML. Molecular and prognostic classification was based on specific chromosomal translocations, deletions, and amplifications ( such as $\mathrm{t}(15 ; 17),-5 \mathrm{q},-7 \mathrm{q},+8)$, the discovery of gene mutations (e.g. FLT3-ITD, CEBPA, NMP1) and oncogene deregulation (e.g. ERG and BAALC overexpression) (ref. ${ }^{90}$ ).

Recent studies revealed dysregulation of multiple miRNAs in AML, for example miR-155, miR196a/b or miR-181. MiR-155 was up-regulated in FLT3-ITD positive adult AML (ref. ${ }^{91}$ ), down-regulation of miR-196a/b was found in adult MLL rearranged AML (ref. ${ }^{92}$ ) and over-expression of miR-181 was associated with a high percentage of blasts in AML with a favorable outcome ${ }^{93}$.

A number of studies focused on the role of miR-29 family members in AML. Results on expression level of miR-29 family members in AML patient samples are, however, quite different. It may be caused by high variability of AML because it is a very heterogeneous disorder and comparing different subtypes of this disease is almost impossible to do.

Han et al. demonstrated high level expression of miR-29a in human AML. The study focused on the function of miR-29a and self-renewal capacity in hematopoietic progenitors. Self-renewal is a property essential to ability to maintain life-long hematopoiesis. Because miR-29a is highly expressed in the majority of human AML tested, their findings provide evidence that miRNAs may serve as robust oncogenes during leukemogenesis and that they may convert myeloid progenitors into leukemia stem cells (LSC) critical for the development of AML $\left(\right.$ ref. $\left.{ }^{94}\right)$. Self-renewal is observed in hematopoietic stem 
cells (HSCs) and also in malignant counterparts of HSC/ progenitors in human AML (ref. ${ }^{95}$ ). Self-renewal is an important property acquired by normal committed progenitors during leukemic transformation and this property is required for the establishment of leukemia stem cells ${ }^{96}$.

Contradicting results were found by Wang et al. who detected down-regulation of miR-29a and miR-142-3p in 52 newly diagnosed AML patients. This finding is universal among the five AML subtypes according to French-American-British classification, i.e. M1, M2, M3, M4 and M5, and may function jointly in granulopoiesis and monopoiesis ${ }^{97}$. Microarray platform used to perform genome wide miRNome analysis of AML samples and normal progenitor CD $34^{+}$cells identified molecular signatures associated with several cytogenetic groups. Downregulation of miR-29a was observed in AML samples with deletions of $7 \mathrm{q}$ (del7q) $\left(\right.$ ref. $\left.^{98}\right)$.

Follow-up study on the influence of miR-29 and miR-142-3p on hematopoiesis in AML demonstrated a positive effect of these miRNAs on the monocytic and granulocytic differentiation (myeloid differentiation) and validated three targets involved in AML development. They used leukemia cell lines NB4, HL60, and THP-1, in which up-regulation of miR-29a and miR-142-3p expression during all-trans-retinoic acid (ATRA)-induced granulocytic differentiation and phorbol 12-myristate 13-acetate (PMA)-induced monocytic differentiation was observed ${ }^{97}$. It is conceivable that miR-29a and miR-142-3p promote myeloid differentiation primarily by affecting CCNT2, CDK6 and TAB2. Significantly increased levels of the target proteins were detected in the AML blast with abnormally reduced expression of miR-29a and miR-142-3p, which further suggested that these two miRNAs regulate myeloid differentiation and AML development via the three target genes ${ }^{98,99}$.

Experimental data indicated that forced expression of miR-29a and miR-29b in AML cell lines and in primary AML blasts inhibited cell growth and induced apoptosis. The apoptotic effect of miR-29s overexpression after transfection in AML cell lines was observed after $48 \mathrm{~h}$, whereas the anti-proliferative effect was noticed earlier at $24 \mathrm{~h}$. These results suggest that miR-29-dependent cell proliferation effects are not the result of apoptosis and are both likely to contribute to the tumor suppressor activity of miR-29s. The tumor suppressor effect of miR-29b in AML was further demonstrated in vivo in a xenograft model. Mice were inoculated by K562 cells thereby inducing tumor growth on their bodies. After 10 and 14 days of injection of synthetic miR-29b directly into the tumors were these significantly smaller and some disappeared completely in contrast to injecting with scrambled oligonucleotides. Restoring miR-29b expression down-modulated Mcl-1, induced apoptosis and dampened cell growth in AML cells, thereby suggesting miRNA-based therapy as a novel pro-apoptotic approach to increase response in AML (ref. ${ }^{42}$ ).

miR-29a and miR-29c were found up-regulated in AML with aberrant cytoplasmic NPM1 localization. AML carrying NPM1 mutations and cytoplasmic nucleophosmin
(NPMc positive AML) account for about one-third of adult AML. A strong miRNA signature that distinguishes NPM1 positive mutated from the cytoplasmic-negative (NPM1 unmutated) cases was identified and included up-regulation of miR-29 family members ${ }^{100}$.

One study observed decreased miR-29a expression in the bone marrow from pediatric patients with newly diagnosed AML, compared with normal controls. The reduced expression of miR-29a was significantly associated with advanced clinical features of pediatric AML patients. Analysis revealed that the expression level of miR-29a was a predictor of shorter relapse-free survival (RFS) and overall survival (OS) independent of the cytogenetic abnormalities. Prognostic value of miR-29a expression was especially more obvious in the subgroup of patients with intermediate risk cytogenetics ${ }^{3}$. This finding is consistent with the previous study showing reduced expression of miR-29a in adult AML patients ${ }^{99}$. In addition it was found that the decreased expression of miR-29a was significantly associated with classification subtype M7 (FAB) and the unfavorable cytogenetic risks ${ }^{3}$.

Epigenetic effects of miR-29 in acute myeloid leukemia were confirmed by identification of DNA methyltransferases (DNMTs) as miR-29 target genes ${ }^{41}$. Silencing of structurally normal tumor suppressor genes by aberrant DNA hypermethylation has been reported in hematologic malignancies, including subsets of acute myeloid leukemia (AML) (ref. ${ }^{101}$ ). Over-expression of miR-29b in AML cells resulted in reduction of the expression of all DNMTs, which led to decrease in DNA methylation and re-expression of $\mathrm{p} 15^{\mathrm{INK} 4 \mathrm{~b}}$ and ESR1 via promoter DNA hypomethylation. Down-regulation of DNMT3A and 3B was the result of a direct interaction with miR-29b. Another experiment revealed that miR-29b down-regulates DNMT1 indirectly by targeting Sp1, a transactivator of the DNMT1gene ${ }^{41}$.

Function of CCAAT/enhancer-binding protein $\alpha$ (CEBPA) is frequently disrupted or mutations in the CEBPA coding regions are present in AML (ref. ${ }^{102}$ ). CEBPA is the key transcription factor for normal haematopoiesis $^{103}$. Relationship between CEBPA and miR-29 in AML was revealed. CEBPA-mediated miR-29b expression indicated that only the miR-29a/b1 locus on chromosome 7q32.3 is activated by CEBPA, whereas miR-29b2/c expression is not affected by CEBPA. These findings suggest a rationale for miR-29b suppression in AML patients with disrupted CEBPA function or with aberrations on chromosome 7 ( ref. $^{12}$ ).

Recent study demonstrated AKT2 and CCND2 mRNA to be targets of the miR-29 family members in AML where increased levels of Akt2, CCND2 and c-Myc were correlated with the decreased miR-29 family members expression in AML blasts. Feed-back loop comprised of c-Myc, miR-29 and Akt 2 was found in myeloid leukemogenesis. Re-expression of miR-29 partially corrected abnormal cell proliferation and apoptosis repression and myeloid differentiation arrest in AML blasts. Moreover, an intravenous injection of miR-29 in the AML model mice relieved leukemic symptoms significantly ${ }^{104}$. 
Mir-29 and its role in chronic myeloid leukemia (CML)

CML is a myeloproliferative neoplasm which is characterized by a translocation between chromosomes 9 and 22, known as the Philadelphia chromosome. It leads to generation of a specific fusion protein - tyrosine kinase $\mathrm{BCR} / \mathrm{ABL}$, which activates multiple signaling pathways leading to proliferation, reduced growth factor dependence and resistance to apoptosis ${ }^{105}$. One study demonstrated that RNase-L expression is post-transcriptionally regulated by the miR-29 family members via 4 target sites in its 3 'UTR (ref. ${ }^{106}$ ). RNase-L is the endoribonuclease that is the terminal component of an interferon-regulated RNA decay pathway known as the $2^{\prime}$-5'-oligoadenylate system whose established function include antimicrobial and tumor suppressive activities ${ }^{107}$. This assignment is contrary to other finding where RNase-L was suggested to play a novel oncogenic function. Transfection of K562 CML cells by miR-29 results in reduced proliferation, enhanced apoptosis and inhibited tumorigenesis. Consistent with this interpretation, stable knockdown of RNase-L, decreased K562 proliferation and inhibited tumorigenesis was found in a xenograft model ${ }^{106}$.

Another study focused on the effect of miR-29 expression on $\mathrm{BCR} / \mathrm{ABL} 1$ protein in CML. It was found that level of miR-29b expression is lower in CML patients compared with normal volunteers and then demonstrated that miR-29b down-regulates ABL1 and BCR/ABL1 expression in K562 CML cells. Finally, it was confirmed that miR-29b suppresses cell proliferation and induces cell apoptosis ${ }^{108}$.
Mir-29 and its role in multiple myeloma (MM)

$\mathrm{MM}$ is one of the most common type of plasma cell cancer. It is a post-germinal center B cell malignancy, characterized by clonal plasma cell expansion within the bone marrow $^{65}$. MM pathogenesis is a multistep process with chromosomal changes, genetic and epigenetic events occurring at different stages during the course of the disease $^{109}$. As we mentioned above, the expression level of miR-29 is also altered in multiple myeloma cells. It was shown in the bone marrow specimens that miR-29b was significantly down-regulated. Perfect complementarity was revealed between miR-29b and the 3'UTR of Mcl-1, which is an anti-apoptotic member of the Bcl-2 family. Moreover, miR-29b partially interrupts the process of IL-6-induced up-regulation of Mcl-1 and suppresses the protective effect of IL-6 in myeloma cells ${ }^{65}$.

Epigenetic events play a major role in MM pathogenesis $^{110}$. It was found that miR-29b targets DNMT3A/B mRNAs and reduces global DNA methylation in MM cells. In vitro transfection of MM cells with synthetic miR$29 \mathrm{~b}$ mimics significantly impairs cell cycle progression and also potentiates the growth-inhibitory effects induced by the demethylating agent 5 -azacytidine ${ }^{111}$. Epigenetical activity of miR-29b leads to promoter demethylation of suppressor of cytokine signaling-1 (SOCS-1), a hypermethylated tumor suppressor gene. MiR-29b-induced SOCS-1 demethylation was associated with reduced STAT3 phosphorylation and impaired NFKB activity ${ }^{112}$.

Table 2. Summary of expression of miR-29 family members in variety of hematopoietic malignancies.

\begin{tabular}{|c|c|c|c|c|}
\hline $\begin{array}{l}\text { Hematopoietic } \\
\text { malignancy }\end{array}$ & $\begin{array}{l}\text { miR-29 family } \\
\text { members }\end{array}$ & $\begin{array}{l}\text { Up/down regula- } \\
\text { tion of expression }\end{array}$ & $\begin{array}{l}\text { In vitro / in vivo } \\
\text { experiments }\end{array}$ & Reference cell/tissue \\
\hline \multirow[t]{4}{*}{ CLL } & $\mathrm{c}$ & $\downarrow$ & in vivo & normal B cells ${ }^{62}$ \\
\hline & $a, b, c$ & $\uparrow \downarrow$ & in vivo & normal B cells ${ }^{84}$ \\
\hline & $\mathrm{b}$ & $\downarrow$ & in vivo & STAT3 non-transfected primary CLL B cells ${ }^{85}$ \\
\hline & $\mathrm{c}$ & $\downarrow$ & in-vivo & CLL B cells with wild-type TP5 $3^{47}$ \\
\hline \multirow[t]{8}{*}{ AML } & $\mathrm{a}$ & $\uparrow$ & in vivo & normal bone marrow mononuclear cells ${ }^{94}$ \\
\hline & $\mathrm{a}$ & $\downarrow$ & in vivo & normal peripheral blood mononuclear cells ${ }^{97}$ \\
\hline & $\mathrm{a}, \mathrm{b}, \mathrm{c}$ & $\downarrow$ & in vivo & AML patients lacking $\mathrm{t}(11 \mathrm{q} 23)^{98}$ \\
\hline & a & $\downarrow$ & in vivo & patients with normal karyotype ${ }^{42}$ \\
\hline & $\mathrm{a}, \mathrm{c}$ & $\uparrow$ & in vivo & cytoplasmic nucleophosmin negative AML patients ${ }^{100}$ \\
\hline & a & $\downarrow$ & in vivo & normal bone marrow ${ }^{3}$ \\
\hline & $\mathrm{b}$ & $\downarrow$ & in vivo & normal mature monocytes and granulocytes ${ }^{12}$ \\
\hline & $a, b, c$ & $\downarrow$ & in vivo & normal CD34+ cells ${ }^{104}$ \\
\hline CML & $\mathrm{b}$ & $\downarrow$ & in vitro & non-transfected K562 cells ${ }^{108}$ \\
\hline MCL & $\mathrm{a}, \mathrm{b}, \mathrm{c}$ & $\downarrow$ & in vivo & normal B lymphocytes ${ }^{8}$ \\
\hline MM & $\mathrm{b}$ & $\downarrow$ & in vitro & human myeloma cell lines ${ }^{65}$ \\
\hline
\end{tabular}

Differences in individual miR-29 family members expression versus the reference cells or tissues or patients is indicated by corresponding arrows. Evidence from in vivo or in vitro studies is referenced. 


\section{CONCLUSION}

Hematopoietic malignancies are very heterogenous regarding genetic background, however, there appear to be some common features apparently governed by miR-29 family members. Targeted manipulation of miR-29 may facilitate current treatments of the malignancies. Because of the known genetic heterogeneity manipulation of miR29 expression in individual, well characterized cells could expedite the development of combined treatments.

\section{ABBREVIATIONS}

3'UTR, 3' untranslated region; ADAM 12, Disintegrin and metalloproteinase domain-containing protein 12; AKT2, RAC-beta serine/threonine-protein kinase; ALL, Acute lymphoblastic leukemia; AML, Acute myeloid leukemia; AP-1, Activator protein 1; ATRA, All-trans-retinoic acid; BAALC, Brain and Acute Leukemia, Cytoplasmic; BACE1, Beta-site APP-cleaving enzyme 1; Bcl-2, B-cell lymphoma 2; B-CLL, B-cell chronic lymphocytic leukemia; BCR, Surface-immunoglobulin B cell receptor; BMP1, Bone morphogenetic protein 1; CCND1, G1/Sspecific cyclin-D1; CCND2, Cyclin D2; CCNT2, Cyclin T2; CDH1, Cadherin 1; CDH13, Cadherin 13; CDK6, Cyclin-dependent kinase 6; CDKN2A, Cyclin-dependent kinase inhibitor 2A; CEBPA, CCAAT/enhancer binding protein $\alpha$; CLL, Chronic lymphoblastic leukemia; CML, Chronic myeloid leukemia; COL1A1, Collagen, type 1, alpha 1; COL3A1, Collagen, type 3, alpha 1; COL4A1, Collagen, type 4, alpha 1; COL4A2, Collagen, type 4, alpha 2; CpG47, 5 -cytosine-guanosine; DKK1, Dickkopf WNT signaling pathway inhibitor 1; DNMT, DNA methyltransferases; E-box, Enhancer Box sequence; ERG, ETSrelated gene; ESR1, Estrogen receptor 1; Ezh2, Enhancer of zeste homolog 2; FHIT, Fragile histidine triad protein; FLT3-ITD, Internal tandem duplications of Fms-Related Tyrosine Kinase 3; GAS, IFN $-\gamma$ - activated sequences; GRN, Granulin; HDAC1, Histone deacetylase 1; HDAC4, Histone deacetylase 4; HMCL, Human Myeloma Cell Line; HMGA2, High mobility group AT-hook2; HSCs, Hematopoietic stem cells; IFN, Interferon; IFN $\alpha$, Interferon alpha; IFN $\beta$, Interferon beta; IFN $\gamma$, Interferon gamma; IFNAR, IFN $\alpha / \beta$ receptor; IL-4, Interleukin 4; IL-6, Interleukin 6; KMCH, Combined hepatocellular and cholangiocarcinoma cell line; Kremen2, Kringle containing transmembrane protein 2; LPL, Lipoprotein lipase; LSC, Leukemia stem cells; Mcl-1, Myeloid cell leukemia 1; miRNA, MicroRNA; MM, Multiple myeloma; MMP2, Matrix metalloproteinase 2; MyoD, Myogenic differentiation 1; NF-kB, Nuclear factor kappa B; NK, Natural killer cell; NMP1, Nuclear matrix protein 1; NPM1, Nucleophosmin 1; NSCLC, Non-small-cell lung cancer; OS, Overall survival; PcG, Polycomb group; PCR, Polymerase chain reaction; PMA, Phorbol 12-myristate 13-acetate; PPM1D, Protein phosphatase $\mathrm{Mg}^{2+}$ $\mathrm{Mn}^{2+}$ dependent, 1D; PIK3R1, Phosphoinositide-3-kinase, regulatory subunit 1; RASSF1A, Ras association domaincontaining protein 1; RFS, Relapse-free survival; RNase-L,
Ribonuclease L; SAPCD2, Suppressor APC domain containing 2; SBE, Smad Binding Element; SERPINB9, Serpin peptidase inhibitor, clade B, member 9; SFRP2, Secreted frizzeled-related protein 2; Smad2, Mothers against decapentaplegic homolog 2; Smad3, Mothers against decapentaplegic homolog 3; Smad7, Mothers against decapentaplegic homolog 7; SOCS-1, Suppressor of cytokine signaling 1; Sp 1, Transcription factor $\mathrm{Sp} 1$ (specificity protein 1); SPARC, Secreted protein, acidic, cysteine-rich; STAT1, Signal Transducer and Activator of Transcription 1; STAT3, Signal Transducer and Activator of Transcription 3; TAB2, TGF-Beta Activated Kinase 1; TCF/LEF, T-cell factor/lymphoid enhancer factor; Tcl-1, T-cell leukemia oncogene; TGF- $\beta$, Tumor growth factor $b$; TLR, Toll-like receptor; TRAIL, Tumor necrosis factor-related apoptosis-inducing ligand; WNT3A, Wingless-Type MMTV Integration Site Family, Member 3A; WWOX, WW domain-containing oxidoreductase; YY1, Yin Yang 1; Zap70, Zeta-chain-associated protein kinase 70 .

\section{ACKNOWLEDGEMENTS}

Authors gratefully acknowledge the help of dr. Patrik Kilian (University of South Bohemia) with graphical design of the figures. The research is supported by grants LF_2013_008 and CZ.1.07/2.4.00/17.0015.

Authorship contributions: SK, MM: literature search; SK, MM: conception and manuscript writing; MM, SV: final approval.

Conflict of interest statement: The authors state that there are no conflicts of interest regarding the publication of this article.

\section{REFERENCES}

1 Lee RC, Feinbaum RL, Ambros V. The C. elegans heterochronic gene lin-4 encodes small RNAs with antisense complementarity to lin-14. Cell 1993;75:843-54.

2 Alvarez-Garcia I, Miska EA. MicroRNA functions in animal development and human disease. Development 2005;132:4653-62.

3 Zhu C, Wang Y, Kuai W, Sun X, Chen H, Hong Z. Prognostic value of miR-29a expression in pediatric acute myeloid leukemia. Clin Biochem 2012;46:49-53.

4 Lagos-Quintana M, Rauhut R, Lendeckel W, Tuschl T. Identification of novel genes coding for small expressed RNAs. Science 2001;294:8538.

5 Hwang HW, Wentzel EA, Mendell JT. A hexanucleotide element directs microRNA nuclear import. Science 2007;315:97-100.

6 Pekarsky Y, Santanam U, Cimmino A, Palamarchuk A, Efanov A, Maximov V, Volinia S, Alder H, Liu CG, Rassenti L, Calin GA, Hagan JP, Kipps T, Croce CM. Tcl1 expression in chronic lymphocytic leukemia is regulated by miR-29 and miR-181. Cancer Res 2006;66:11590-3.

7 Mott JL, Kobayashi S, Bronk SF, Gores G.J mir-29 regulates Mcl-1 protein expression and apoptosis. Oncogene 2007;26:6133-40.

8 Zhao JJ, Lin J, Lwin T, Yang H, Guo J, Kong W, Dessureault S, Moscinski LC, Rezania D, Dalton WS, Sotomayor E, Tao J, Cheng JQ. microRNA expression profile and identification of miR-29 as a prognostic marker and pathogenetic factor by targeting CDK6 in mantle cell lymphoma. Blood 2010;115:2630-9.

9 Sempere LF, Freemantle S, Pitha-Rowe I, Moss E, Dmitrovsky E, Ambros V. Expression profiling of mammalian microRNAs uncovers a subset of brain-expressed microRNAs with possible roles in murine and human neuronal differentiation. Genome Biol 2004;5:R13. 
10 Chang TC, Yu D, Lee YS, Wentzel EA, Arking DE, West KM, Dang CV, Thomas-Tikhonenko A, Mendell JT. Widespread microRNA repression by Myc contributes to tumorigenesis. Nat Genet 2008;40:43-50.

11 Mott JL, Kurita S, Cazanave SC, Bronk SF, Werneburg NW, FernandezZapico ME. Transcriptional suppression of mir-29b-1/mir-29a promoter by c-Myc, hedgehog, and NF-kappaB. J Cell Biochem 2010;110:1155-64.

12 Eyholzer M, Schmid S, Wilkens L, Mueller BU, Pabst T. The tumoursuppressive miR-29a/b1 cluster is regulated by CEBPA and blocked in human AML. Br J Cancer 2010;103:275-84.

13 Kapinas K, Kessler C, Ricks T, Gronowicz G, Delany AM. miR-29 modulates Wnt signaling in human osteoblasts through a positive feedback loop. J Biol Chem 2010;285:25221-31.

14 Schmitt MJ, Philippidou D, Reinsbach SE, Margue C, WieneckeBaldacchino A, Nashan D, Behrmann I, Kreis S. Interferongamma-induced activation of Signal Transducer and Activator of Transcription 1 (STAT1) up-regulates the tumor suppressing microRNA-29 family in melanoma cells. Cell Commun Signal 2012;10:41.

15 Kortylewski M, Komyod W, Kauffmann ME, Bosserhoff A, Heinrich PC, Behrmann I. Interferon-gamma-mediated growth regulation of melanoma cells: involvement of STAT1-dependent and STAT1independent signals. J Invest Dermatol 2004;122:414-22.

16 Reinsbach S, Nazarov PV, Philippidou D, Schmitt M, WieneckeBaldacchino A, Muller A, Vallar L, Behrmann I, Kreis S. Dynamic regulation of microRNA expression following interferon-gamma-induced gene transcription. RNA Biol 2012;9:978-89.

17 Wang H, Garzon R, Sun H, Ladner KJ, Singh R, Dahlman J, Cheng A, Hall BM, Qualman SJ, Chandler DS, Croce CM, Guttridge DC. NFkappaB-YY1-miR-29 regulatory circuitry in skeletal myogenesis and rhabdomyosarcoma. Cancer Cell 2008;14:369-81.

18 Wang H, Hertlein E, Bakkar N, Sun H, Acharyya S, Wang J, Carathers M, Davuluri R, Guttridge DC. NF-kappaB regulation of YY1 inhibits skeletal myogenesis through transcriptional silencing of myofibrillar genes. Mol Cell Biol 2007;27:4374-87.

19 Winbanks CE, Wang B, Beyer C, Koh P, White L, Kantharidis P, Gregorevic P. TGF-beta regulates miR-206 and miR-29 to control myogenic differentiation through regulation of HDAC4. J Biol Chem 2011;286:13805-14.

20 Li Y, Foster W, Deasy BM, Chan Y, Prisk V, Tang Y, Cummins J, Huard J. Transforming growth factor-beta 1 induces the differentiation of myogenic cells into fibrotic cells in injured skeletal muscle: a key event in muscle fibrogenesis. Am J Pathol 2004;164:1007-19.

21 Cencetti F, Bernacchioni C, Nincheri P, Donati C, Bruni P. Transforming growth factor-beta1 induces transdifferentiation of myoblasts into myofibroblasts via up-regulation of sphingosine kinase-1/S1P3 axis. Mol Biol Cell 2010;21:1111-24.

22 Zhou L, Wang L, Lu L, Jiang P, Sun H, Wang H. Inhibition of miR-29 by TGF-beta-Smad3 signaling through dual mechanisms promotes transdifferentiation of mouse myoblasts into myofibroblasts. PLoS One 2012;7:e33766.

23 Sabourin LA, Rudnicki MA. The molecular regulation of myogenesis. Clin Genet 2000:57:16-25.

24 Zhang Z, Zou J, Wang GK, Zhang JT, Huang S, Qin YW, Jing Q. Uracils at nucleotide position 9-11 are required for the rapid turnover of miR-29 family. Nucleic Acids Res 2011;39:4387-95.

25 Dooley J, Liston A. Molecular control over thymic involution: from cytokines and microRNA to aging and adipose tissue. Eur J Immunol 2012;42:1073-9.

26 Samuel CE. Antiviral actions of interferons. Clin Microbiol Rev 2001;14:778-809, table of contents.

27 Papadopoulou AS, Dooley J, Linterman MA, Pierson W, Ucar O, Kyewski B, Zuklys S, Hollander GA, Matthys P, Gray DH, De Strooper $B$, Liston $A$. The thymic epithelial microRNA network elevates the threshold for infection-associated thymic involution via miR-29a mediated suppression of the IFN-alpha receptor. Nat Immunol 2012;13:181-7.

28 Liston A, Papadopoulou AS, Danso-Abeam D, Dooley J. MicroRNA-29 in the adaptive immune system: setting the threshold. Cell Mol Life Sci 2012;69:3533-41.

29 Ma F, Xu S, Liu X, Zhang Q, Xu X, Liu M, Hua M, Li N, Yao H, Cao X. The microRNA miR-29 controls innate and adaptive immune responses to intracellular bacterial infection by targeting interferon-gamma. Nat Immunol 2011;12:861-9.

30 Steiner DF, Thomas MF, Hu JK, Yang Z, Babiarz JE, Allen CD, Matloubian M, Blelloch $\mathrm{R}$, Ansel KM. MicroRNA-29 regulates T-box transcription factors and interferon-gamma production in helper $\mathrm{T}$ cells. Immunity 2011;35:169-81.

31 Kriegel AJ, Liu Y, Fang Y, Ding X, Liang M. The miR-29 family: genomics, cell biology, and relevance to renal and cardiovascular injury. Physiol Genomics 2012;44:237-44.

32 Santanam U, Zanesi N, Efanov A, Costinean S, Palamarchuk A, Hagan JP, Volinia S, Alder H, Rassenti L, Kipps T, Croce CM, Pekarsky Y. Chronic lymphocytic leukemia modeled in mouse by targeted miR-29 expression. Proc Natl Acad Sci U S A 2010;107:12210-5.

33 Sengupta $S$, den Boon JA, Chen IH, Newton MA, Stanhope SA Cheng YJ, Chen CJ, Hildesheim A, Sugden B, Ahlquist P. MicroRNA $29 \mathrm{C}$ is down-regulated in nasopharyngeal carcinomas, up-regulating mRNAs encoding extracellular matrix proteins. Proc Natl Acad Sci U S A 2008;105:5874-8.

34 Fang JH, Zhou HC, Zeng C, Yang J, Liu Y, Huang X, Zhang JP, Guan $X Y$, Zhuang SM. MicroRNA-29b suppresses tumor angiogenesis, invasion, and metastasis by regulating matrix metalloproteinase 2 expression. Hepatology 2011;54:1729-40.

35 Li Z, Hassan MQ, Jafferji M, Aqeilan RI, Garzon R, Croce CM, van Wijnen AJ, Stein JL, Stein GS, Lian JB. Biological functions of miR$29 \mathrm{~b}$ contribute to positive regulation of osteoblast differentiation. J Biol Chem 2009;284:15676-84.

36 Liu Y, Taylor NE, Lu L, Usa K, Cowley AW, Jr., Ferreri NR, Yeo NC, Liang M. Renal medullary microRNAs in Dahl salt-sensitive rats: miR$29 \mathrm{~b}$ regulates several collagens and related genes. Hypertension 2010;55:974-82.

$37 \mathrm{Xu} \mathrm{H}$, Cheung IY, Guo HF, Cheung NK. MicroRNA miR-29 modulates expression of immunoinhibitory molecule B7-H3: potential implications for immune based therapy of human solid tumors. Cancer Res 2009;69:6275-81.

38 Hsu SD, Tseng YT, Shrestha S, Lin YL, Khaleel A, Chou CH, Chu CF, Huang HY, Lin CM, Ho SY, Jian TY, Lin FM, Chang TH, Weng SL, Liao KW, Liao IE, Liu CC, Huang HD. miRTarBase update 2014: an information resource for experimentally validated miRNA-target interactions. Nucleic Acids Res 2014;42:D78-85.

39 Ogawa T, lizuka M, Sekiya Y, Yoshizato K, Ikeda K, Kawada N. Suppression of type I collagen production by microRNA-29b in cultured human stellate cells. Biochem Biophys Res Commun 2010;391:316-21.

40 Steele R, Mott JL, Ray RB. MBP-1 upregulates miR-29b that represses Mcl-1, collagens, and matrix-metalloproteinase-2 in prostate cancer cells. Genes Cancer 2010;1:381-87.

41 Garzon R, Liu S, Fabbri M, Liu Z, Heaphy CE, Callegari E, Schwind S, Pang J, Yu J, Muthusamy N, Havelange V, Volinia S, Blum W, Rush LJ, Perrotti D, Andreeff M, Bloomfield CD, Byrd JC, Chan K, Wu LC, Croce CM, Marcucci G. MicroRNA-29b induces global DNA hypomethylation and tumor suppressor gene reexpression in acute myeloid leukemia by targeting directly DNMT3A and 3B and indirectly DNMT1. Blood 2009;113:6411-8.

42 Garzon R, Heaphy CE, Havelange V, Fabbri M, Volinia S, Tsao T, Zanesi N, Kornblau SM, Marcucci G, Calin GA, Andreeff M, Croce CM. MicroRNA 29b functions in acute myeloid leukemia. Blood 2009;114:5331-41.

43 Fabbri M, Garzon R, Cimmino A, Liu Z, Zanesi N, Callegari E, Liu S, Alder $\mathrm{H}$, Costinean S, Fernandez-Cymering C, Volinia S, Guler G, Morrison CD, Chan KK, Marcucci G, Calin GA, Huebner K, Croce CM MicroRNA-29 family reverts aberrant methylation in lung cancer by targeting DNA methyltransferases $3 \mathrm{~A}$ and 3B. Proc Natl Acad Sci U S A 2007;104:15805-10.

44 Kovalchuk O, Zemp FJ, Filkowski JN, Altamirano AM, Dickey JS Jenkins-Baker G, Marino SA, Brenner DJ, Bonner WM, Sedelnikova OA. microRNAome changes in bystander three-dimensional human tissue models suggest priming of apoptotic pathways. Carcinogenesis 2010;31:1882-8.

45 Du B, Ma LM, Huang MB, Zhou H, Huang HL, Shao P, Chen YQ, Qu $\mathrm{LH}$. High glucose down-regulates miR-29a to increase collagen IV production in HK-2 cells. FEBS Lett; 584:811-6.

46 Wang C, Gao C, Zhuang JL, Ding C, Wang Y. A combined approach identifies three mRNAs that are down-regulated by microRNA-29b and promote invasion ability in the breast cancer cell line MCF-7. J Cancer Res Clin Oncol 2012;138:2127-36.

47 Mraz M, Pospisilova S, Malinova K, Slapak I, Mayer J. MicroRNAs in chronic lymphocytic leukemia pathogenesis and disease subtypes. Leuk Lymphoma 2009;50:506-9. 
48 Xiong Y, Fang JH, Yun JP, Yang J, Zhang Y, Jia WH, Zhuang SM. Effects of microRNA-29 on apoptosis, tumorigenicity, and prognosis of hepatocellular carcinoma. Hepatology 2010;51:836-45.

49 Meng XZ, Zheng TS, Chen X, Wang JB, Zhang WH, Pan SH, Jiang HC, Liu LX. microRNA expression alteration after arsenic trioxide treatment in HepG-2 cells. J Gastroenterol Hepatol;26:186-93.

50 Park SY, Lee JH, Ha M, Nam JW, Kim VN. miR-29 miRNAs activate p53 by targeting p85 alpha and CDC42. Nat Struct Mol Biol 2009;16:23-9.

51 Efanov A, Zanesi N, Nazaryan N, Santanam U, Palamarchuk A, Croce CM, Pekarsky Y. CD5+CD23+ leukemic cell populations in TCL1 transgenic mice show significantly increased proliferation and Akt phosphorylation. Leukemia 2010;24:970-5.

52 Jiao J, Herl LD, Farese RV, Gao FB. MicroRNA-29b regulates the expression level of human progranulin, a secreted glycoprotein implicated in frontotemporal dementia. PLoS One 2010;5:e10551.

53 Maurer B, Stanczyk J, Jungel A, Akhmetshina A, Trenkmann M, Brock M, Kowal-Bielecka O, Gay RE, Michel BA, Distler JH, Gay S, Distler O. MicroRNA-29, a key regulator of collagen expression in systemic sclerosis. Arthritis Rheum 2010;62:1733-43.

54 Chen T, Li Z, Tu J, Zhu W, Ge J, Zheng X, Yang L, Pan X, Yan H, Zhu J. MicroRNA-29a regulates pro-inflammatory cytokine secretion and scavenger receptor expression by targeting LPL in oxLDL-stimulated dendritic cells. FEBS Lett 2011;585:657-63.

55 Wu J, Liu Z, Shao C, Gong Y, Hernando E, Lee P, Narita M, Muller W, Liu J, Wei JJ. HMGA2 overexpression-induced ovarian surface epithelial transformation is mediated through regulation of EMT genes. Cancer Res 2011;71:349-59.

56 Cui Y, Su WY, Xing J, Wang YC, Wang P, Chen XY, Shen ZY, Cao H, Lu YY, Fang JY. MiR-29a inhibits cell proliferation and induces cell cycle arrest through the downregulation of p42.3 in human gastric cancer. PLoS One 2011;6:e25872.

57 Russ AC, Sander S, Luck SC, Lang KM, Bauer M, Rucker FG, Kestler HA, Schlenk RF, Dohner H, Holzmann K, Dohner K, Bullinger L. Integrative nucleophosmin mutation-associated microRNA and gene expression pattern analysis identifies novel microRNA - target gene interac tions in acute myeloid leukemia. Haematologica 2011; 96:1783-91.

58 Zong Y, Wang H, Dong W, Quan X, Zhu H, Xu Y, Huang L, Ma C Qin C. miR-29c regulates BACE1 protein expression. Brain Res 2011;1395:108-15.

59 Virgilio L, Narducci MG, Isobe M, Billips LG, Cooper MD, Croce CM, Russo G. Identification of the TCL1 gene involved in T-cell malignancies. Proc Natl Acad Sci U S A 1994;91:12530-4

60 Laine J, Kunstle G, Obata T, Sha M, Noguchi M. The protooncogene TCL1 is an Akt kinase coactivator. Mol Cell 2000;6:395-407.

61 Herling M, Patel KA, Khalili J, Schlette E, Kobayashi R, Medeiros LJ Jones D. TCL1 shows a regulated expression pattern in chronic lymphocytic leukemia that correlates with molecular subtypes and proliferative state. Leukemia 2006;20:280-5.

62 Stamatopoulos B, Meuleman N, Haibe-Kains B, Saussoy P, Van Den Neste E, Michaux L, Heimann P, Martiat P, Bron D, Lagneaux L. microRNA-29c and microRNA-223 down-regulation has in vivo significance in chronic lymphocytic leukemia and improves disease risk stratification. Blood 2009;113:5237-45

63 Chen L, Willis SN, Wei A, Smith BJ, Fletcher JI, Hinds MG, Colman PM, Day CL, Adams JM, Huang DC. Differential targeting of prosurvival $\mathrm{BCl}-2$ proteins by their $\mathrm{BH} 3$-only ligands allows complementary apoptotic function. Mol Cell 2005; 17:393-403.

64 Opferman JT, Letai A, Beard C, Sorcinelli MD, Ong CC, Korsmeyer SJ Development and maintenance of $B$ and $T$ lymphocytes requires antiapoptotic MCL-1. Nature 2003; 426:671-6.

65 Zhang YK, Wang H, Leng Y, Li ZL, Yang YF, Xiao FJ, Li QF, Chen XQ, Wang LS. Overexpression of microRNA-29b induces apoptosis of multiple myeloma cells through down regulating $\mathrm{Mcl}-1$. Biochem Biophys Res Commun 2011;414:233-9.

66 Jeltsch A. Beyond Watson and Crick: DNA methylation and molecular enzymology of DNA methyltransferases. Chembiochem 2002;3:27493.

67 Jones PA, Baylin SB. The fundamental role of epigenetic events in cancer. Nat Rev Genet 2002;3:415-28.

68 Okano M, Bell DW, Haber DA, Li E. DNA methyltransferases Dnmt3a and Dnmt3b are essential for de novo methylation and mammalian development. Cell 1999;99:247-57.

69 Ulivi P, Zoli W, Calistri D, Fabbri F, Tesei A, Rosetti M, Mengozzi M, Amadori D. p16INK4A and CDH13 hypermethylation in tumor and serum of non-small cell lung cancer patients. J Cell Physiol 2006;206:611-5.

70 Fabbri M, Iliopoulos D, Trapasso F, Aqeilan RI, Cimmino A, Zanesi N Yendamuri S, Han SY, Amadori D, Huebner K, Croce CM. WWOX gene restoration prevents lung cancer growth in vitro and in vivo. Proc Natl Acad Sci U S A 2005;102:15611-6.

71 Iliopoulos D, Guler G, Han SY, Johnston D, Druck T, McCorkell KA, Palazzo J, McCue PA, Baffa R, Huebner K. Fragile genes as biomarkers: epigenetic control of WWOX and FHIT in lung, breast and bladder cancer. Oncogene 2005;24:1625-33.

72 Suzuki M, Sunaga N, Shames DS, Toyooka S, Gazdar AF, Minna JD. RNA interference-mediated knockdown of DNA methyltransferase 1 leads to promoter demethylation and gene re-expression in human lung and breast cancer cells. Cancer Res 2004;64:3137-43.

73 Yanaihara N, Caplen N, Bowman E, Seike M, Kumamoto K, Yi M, Stephens RM, Okamoto A, Yokota J, Tanaka T, Calin GA, Liu CG, Croce CM, Harris CC. Unique microRNA molecular profiles in lung cancer diagnosis and prognosis. Cancer Cell 2006;9:189-98.

74 Blum W, Klisovic RB, Hackanson B, Liu Z, Liu S, Devine H, Vukosavljevic T, Huynh L, Lozanski G, Kefauver C, Plass C, Devine SM, Heerema NA, Murgo A, Chan KK, Grever MR, Byrd JC, Marcucci G. Phase I study of decitabine alone or in combination with valproic acid in acute myeloid leukemia. J Clin Oncol 2007;25:3884-91.

75 Takada S, Berezikov E, Choi YL, Yamashita Y, Mano H. Potential role of miR-29b in modulation of Dnmt3a and Dnmt3b expression in primordial germ cells of female mouse embryos. RNA 2009;15:150714

76 Nguyen T, Kuo C, Nicholl MB, Sim MS, Turner RR, Morton DL, Hoon DS. Downregulation of microRNA-29c is associated with hypermethylation of tumor-related genes and disease outcome in cutaneous melanoma. Epigenetics 2011;6:388-94.

77 Pekarsky Y, Zanesi N, Croce CM. Molecular basis of CLL. Semin Cancer Biol 2010; 20:370-6

78 Aqeilan RI, Calin GA, Croce CM. miR-15a and miR-16-1 in cancer: discovery, function and future perspectives. Cell Death Differ 2010;17:215-20.

79 Calin GA, Dumitru CD, Shimizu M, Bichi R, Zupo S, Noch E, Aldler H, Rattan S, Keating M, Rai K, Rassenti L, Kipps T, Negrini M, Bullrich F, Croce CM. Frequent deletions and down-regulation of micro- RNA genes miR15 and miR16 at 13q14 in chronic lymphocytic leukemia. Proc Natl Acad Sci U S A 2002;99:15524-9.

80 Cimmino A, Calin GA, Fabbri M, lorio MV, Ferracin M, Shimizu M, Wojcik SE, Aqeilan RI, Zupo S, Dono M, Rassenti L, Alder H, Volinia S, Liu CG, Kipps TJ, Negrini M, Croce CM. miR-15 and miR16 induce apoptosis by targeting BCL2. Proc Natl Acad Sci U S A 2005;102:13944-9.

81 Pekarsky Y, Koval A, Hallas C, Bichi R, Tresini M, Malstrom S, Russo G, Tsichlis $\mathrm{P}, \mathrm{Croce} \mathrm{CM}$. Tcl1 enhances Akt kinase activity and mediates its nuclear translocation. Proc Natl Acad Sci U S A 2000;97:3028-33.

82 Pekarsky Y, Palamarchuk A, Maximov V, Efanov A, Nazaryan N Santanam U, Rassenti L, Kipps T, Croce CM. Tcl1 functions as a transcriptional regulator and is directly involved in the pathogenesis of CLL. Proc Natl Acad Sci U S A 2008;105:19643-8.

83 Calin GA, Ferracin M, Cimmino A, Di Leva G, Shimizu M, Wojcik SE Iorio MV, Visone R, Sever NI, Fabbri M, luliano R, Palumbo T, Pichiorr F, Roldo C, Garzon R, Sevignani C, Rassenti L, Alder H, Volinia S, Liu CG, Kipps TJ, Negrini M, Croce CM. A MicroRNA signature associated with prognosis and progression in chronic lymphocytic leukemia. $\mathrm{N}$ Engl J Med 2005; 353:1793-801.

84 Sampath D, Liu C, Vasan K, Sulda M, Puduvalli VK, Wierda WG, Keating MJ. Histone deacetylases mediate the silencing of miR15a, miR-16, and miR-29b in chronic lymphocytic leukemia. Blood 2012;119:1162-72

85 Rozovski U, Calin GA, Setoyama T, D'Abundo L, Harris DM, Li P, Liu Z, Grgurevic S, Ferrajoli A, Faderl S, Burger JA, O'Brien S, Wierda WG, Keating MJ, Estrov Z. Signal transducer and activator of transcription (STAT)-3 regulates microRNA gene expression in chronic lymphocytic leukemia cells. Mol Cancer 2013;12:50

86 Liu Z, Hazan-Halevy I, Harris DM, Li P, Ferrajoli A, Faderl S, Keating MJ, Estrov Z. STAT-3 activates NF-kappaB in chronic lymphocytic leukemia cells. Mol Cancer Res 2011;9:507-15.

87 Kluiver JL, Chen CZ. MicroRNAs regulate B-cell receptor signalinginduced apoptosis. Genes Immun 2012;13:239-44.

88 Mraz M, Kipps TJ. MicroRNAs and B cell receptor signaling in chronic lymphocytic leukemia. Leuk Lymphoma 2013;54:1836-9. 
89 Frohling S, Scholl C, Gilliland DG, Levine R.L Genetics of myeloid malignancies: pathogenetic and clinical implications. J Clin Oncol 2005;23:6285-95.

90 Mrozek K, Marcucci G, Paschka P, Whitman SP, Bloomfield CD. Clinical relevance of mutations and gene-expression changes in adult acute myeloid leukemia with normal cytogenetics: are we ready for a prognostically prioritized molecular classification? Blood 2007;109:43148.

91 Forrest AR, Kanamori-Katayama M, Tomaru Y, Lassmann T, Ninomiya N, Takahashi Y, de Hoon MJ, Kubosaki A, Kaiho A, Suzuki M, Yasuda J, Kawai J, Hayashizaki Y, Hume DA, Suzuki H. Induction of microRNAs, mir-155, mir-222, mir-424 and mir-503, promotes monocytic differentiation through combinatorial regulation. Leukemia 2010;24:4606.

92 Danen-van Oorschot AA, Kuipers JE, Arentsen-Peters S, Schotte D, de Haas V, Trka J, Baruchel A, Reinhardt D, Pieters R, Zwaan CM, van den Heuvel-Eibrink MM. Differentially expressed miRNAs in cytogenetic and molecular subtypes of pediatric acute myeloid leukemia. Pediatr Blood Cancer 2012;58:715-21.

93 Schwind S, Maharry K, Radmacher MD, Mrozek K, Holland KB Margeson D, Whitman SP, Hickey C, Becker H, Metzeler KH, Paschka P, Baldus CD, Liu S, Garzon R, Powell BL, Kolitz JE, Carroll AJ, Caligiur MA, Larson RA, Marcucci G, Bloomfield CD. Prognostic significance of expression of a single microRNA, miR-181a, in cytogenetically normal acute myeloid leukemia: a Cancer and Leukemia Group B study. J Clin Oncol 2009;28:5257-64.

94 Han YC, Park CY, Bhagat G, Zhang J, Wang Y, Fan JB, Liu M, Zou Y, Weissman IL, Gu H. microRNA-29a induces aberrant self-renewal capacity in hematopoietic progenitors, biased myeloid development, and acute myeloid leukemia. J Exp Med 2010;207:475-89.

95 Bonnet D, Dick JE. Human acute myeloid leukemia is organized as a hierarchy that originates from a primitive hematopoietic cell. Nat Med 1997;3:730-7.

96 Passegue E, Jamieson CH, Ailles LE, Weissman IL. Normal and leukemic hematopoiesis: are leukemias a stem cell disorder or a reacquisition of stem cell characteristics? Proc Natl Acad Sci U S A 2003; 100 Suppl 1:11842-9.

97 Wang F, Wang XS, Yang GH, Zhai PF, Xiao Z, Xia LY, Chen LR, Wang Y, Wang XZ, Bi LX, Liu N, Yu Y, Gao D, Huang BT, Wang J, Zhou DB, Gong JN, Zhao HL, Bi XH, Yu J, Zhang JW. miR-29a and miR-142-3p downregulation and diagnostic implication in human acute myeloid leukemia. Mol Biol Rep 2012;39:2713-22.

98 Garzon R, Volinia S, Liu CG, Fernandez-Cymering C, Palumbo T, Pichiorri F, Fabbri M, Coombes K, Alder H, Nakamura T, Flomenberg N, Marcucci G, Calin GA, Kornblau SM, Kantarjian H, Bloomfield $C D$, Andreeff M, Croce CM. MicroRNA signatures associated with cytogenetics and prognosis in acute myeloid leukemia. Blood 2008; 111:3183-9.

99 Wang XS, Gong JN, Yu J, Wang F, Zhang XH, Yin XL, Tan ZQ, Luo ZM, Yang GH, Shen C, Zhang JW. MicroRNA-29a and microRNA-142-3p are regulators of myeloid differentiation and acute myeloid leukemia. Blood 2012;119:4992-5004.
100 Garzon R, Garofalo M, Martelli MP, Briesewitz R, Wang L, FernandezCymering C, Volinia S, Liu CG, Schnittger S, Haferlach T, Liso A, Diverio D, Mancini M, Meloni G, Foa R, Martelli MF, Mecucci C, Croce CM, Falini B. Distinctive microRNA signature of acute myeloid leukemia bearing cytoplasmic mutated nucleophosmin. Proc Natl Acad Sci U S A 2008;105:3945-50.

101 Mizuno S, Chijiwa T, Okamura T, Akashi K, Fukumaki Y, Niho Y, Sasaki $H$. Expression of DNA methyltransferases DNMT1, 3A, and 3B in normal hematopoiesis and in acute and chronic myelogenous leukemia. Blood 2001;97:1172-9.

102 Pabst T, Mueller BU. Transcriptional dysregulation during myeloid transformation in AML. Oncogene 2007;26:6829-37.

103 Radomska HS, Huettner CS, Zhang P, Cheng T, Scadden DT, Tenen DG. CCAAT/enhancer binding protein alpha is a regulatory switch sufficient for induction of granulocytic development from bipotential myeloid progenitors. Mol Cell Biol 1998;18:4301-14.

104 Gong JN, Yu J, Lin HS, Zhang XH, Yin XL, Xiao Z, Wang F, Wang XS, Su R, Shen C, Zhao HL, Ma YN, Zhang JW. The role, mechanism and potentially therapeutic application of microRNA-29 family in acute myeloid leukemia. Cell Death Differ 2014;21:100-12.

105 Jabbour E, Kantarjian H. Chronic myeloid leukemia: 2012 up date on diagnosis, monitoring, and management. Am J Hematol 2012;87:1037-45.

106 Lee TY, Ezelle HJ, Venkataraman T, Lapidus RG, Scheibner KA, Hassel $B A$. Regulation of human RNase-L by the miR-29 family reveals a novel oncogenic role in chronic myelogenous leukemia. J Interferon Cytokine Res 2012;33:34-42.

107 Hassel BA, Zhou A, Sotomayor C, Maran A, Silverman RH. A dominant negative mutant of 2-5A-dependent RNase suppresses antiproliferative and antiviral effects of interferon. EMBO J 1993;12:3297-304.

108 Li Y, Wang H, Tao K, Xiao Q, Huang Z, Zhong L, Cao W, Wen J, Feng W. miR-29b suppresses CML cell proliferation and induces apoptosis via regulation of BCR/ABL1 protein. Exp Cell Res 2013;319:1094-101.

109 Palumbo A, Anderson K. Multiple myeloma. N Engl J Med 2011; 364:1046-60.

110 Galm O, Wilop S, Reichelt J, Jost E, Gehbauer G, Herman JG, Osieka R. DNA methylation changes in multiple myeloma. Leukemia 2004;18:1687-92.

111 Amodio N, Leotta M, Bellizzi D, Di Martino MT, D'Aquila P, Lionetti M, Fabiani F, Leone E, Gulla AM, Passarino G, Caraglia M, Negrini M, Neri A, Giordano A, Tagliaferri P, Tassone P. DNA-demethylating and antitumor activity of synthetic miR-29b mimics in multiple myeloma. Oncotarget 2012;3:1246-58.

112 Amodio N, Bellizzi D, Leotta M, Raimondi L, Biamonte L, D'Aquila P, Di Martino MT, Calimeri T, Rossi M, Lionetti M, Leone E, Passarino G, Neri A, Giordano A, Tagliaferri P, Tassone P. miR-29b induces SOCS-1 expression by promoter demethylation and negatively regulates migration of multiple myeloma and endothelial cells. Cell Cycle 2013; 12:3650-62 